\title{
PARTICIPATORY SUSTAINABILITY BEYOND TECHNO-AESTHETICISM AND ECOLOGICAL MODERNISATION
}

\author{
A B S T R A C T
}

The dispersed interpretation of ecological issues in architecture creates grounds for the confusions and contradictions inherent in the sustainable challenges. The relationship between sustainability and its architectural representation remains a troubled one. In contemporary architectural praxis the term sustainability is frequently little more than a fashionable phrase or comfort word. Through analysis of the myriad of projects, articles, and books on the subject of sustainable design, it is evident that sustainable architecture has incorporated an unnecessarily limited and inappropriate conceptualisation of social ecology. In order to overcome this deductive logic of sustainable architecture this paper has two aims. First, it investigates different notions of ecological sustainability. The paper argues that we must fundamentally revise the focus and scope of the debate about sustainable architecture. Second, following the work of Chilean architects Elemental, this paper elucidates issues of design process in constructing residence units with respect to participatory practices of community members. It explores a design process of housing in relation to issues of socio-ecological aspects. Concretising the argument, this paper investigates competing interpretations of ecological and sociological features in architectural process of designing residence units.

\section{Goran Ivo Marinović}

Universidad de las Américas Puebla, Department of Architecture, Mexico 


\section{INTRODUCTION: PLATFORM FOR SOCIAL SUSTAINABILITY}

Brian Edwards argued that "social, ecological, and cultural sustainability will be the measures for tomorrow's buildings". He claimed further that the measures of these buildings will "[fuse] a solid technological base, social sustainability, productivity and social cohesion based on healthy life styles." ${ }^{11}$ In contrast to this optimistic anticipation of tomorrow's buildings, however, the technological approach is dominant and seems to eclipse other modes of sustainability, such as the social aspect. Technologically-driven sustainable innovation often comes with novel formal and spatial features, joining technology and aestheticism to reinforce its attractiveness. Along with the high cost of maintenance, technoaesthetic design that labels itself as an exemplary form of sustainability is something less-developed countries find unaffordable and difficult to properly realise. Indeed, the "sustainable architecture" imposed by economically developed countries equipped with a variety of technological devices acts as an overarching umbrella that fails to acknowledge local specificities.

On the other hand, Simon Guy and Graham Farmer defined "the concept of green building" as "a social construction". ${ }^{2}$ Aside from responding to ecological requirements such as reducing the consumption of fossil-based energy, sustainable architecture should engage with the social setting of a given community and reexamine the position of the architect. In addition to relying on conventional architectural tools of design - such as models, drawings and mockups - for the realisation of a sustainable design, architects are required to directly engage with the community. In order to produce a design that works properly for a particular society, the architect must adopt the role of mediator between different social actors and design solutions. Social sustainability subsequently becomes a highly contextualised design practice with the intent to uncover stakeholders' economical, congregational, political, ethical and spiritual needs. Social sustainability operates upon the participation of the users who will commission, develop, manage and evaluate the setting of their own housing and neighborhood. In this context, Guy and Farmer wrote that sustainability in architecture "suggests the creation of buildings that embody and express the notion of a social and ecological community in which democratic values such as full participation and freedom is the norm."

The goal of this paper is to establish a platform for social sustainability beyond techno-aesthetic innovations that claim to be universally sustainable. The paper first analyses and criticises the techno-aesthetic approach by reviewing related literature and by taking as a case study of Jean Nouvel's social housing project 
in Nimes, France, entitled Nemausus I \& II (1987). The second section of the paper is devoted to the criticism of what is called ecological modernisation that takes the contemporary environmental crisis as an opportunity to reformat the industrial structure globally. This section will review William McDonough's notion of ecology, its relationship with industries, and his practice. The last section of the paper delves into the significance of social sustainability that acknowledges the specificity of a local situation by having future tenants participate in the process of design and construction. To concretise the argument, the paper will introduce and analyse Villa Verde (2010), a Chilean social housing project by Elemental.

\section{TECHNO-AESTHETIC APPROACH AND ITS LIMITS}

Bartleby the Scrivener: A Story of Wall Street, Herman Melville's short story, is an uncomfortable and amusing text. The refrain of Melville's protagonists, "I would prefer not to", is what linguists call "grammaticality". By this term linguists mean something that seeks the limits of grammatical variables in poetry and prose. As Joseph Jaworski explained, by using this phrase, Bartleby "does not refuse, but neither does he accept, he advances and then withdraws into this advance, barely exposing himself in a nimble retreat from speech." Within this language, he survives only by a suspension of values, which keeps the encroachments of life at a safe distance. This powerful phrase is a form of passivity, neither an affirmation nor denial. Bartleby is captured within his refrain, which creates a negative logic beyond all negativity. In the words of Gilles Deleuze (1925-1995), "the formula I prefer not to excludes all alternatives, and devours what it claims to conserve no less than it distances itself from everything else". From this, Deleuze goes further to argue that, "if Bartleby had refused, he could still be seen as a rebel or insurrectionary and as such would still have a social role. But the formula stymies all speech acts, and at the same time, it makes Bartleby a pure outsider (exclu) to whom no social position can be attributed."

Bartleby's passivity, embodied within indetermination between non-preferred activities and preferable actions, is analogous to the architects involved in sustainable issues who avoid social questions in the design process. Sustainable architecture is persistently defined as an enclosed unity, distancing itself from the plurality of positions, values and ideas. As Richard Rorty (1931-2007) points out, treating sustainability as a unified set of technological rules and devices, such as photovoltaic solar panels and mechanised facade systems, eliminates 
possibilities for alternative views to the current environmental crisis. ${ }^{6}$ Bartleby's passivity is present in this type of architectural practice in which technological simplification nullifies the complex social aspect of sustainable design. The social conditions of sustainable architecture are usually presupposed or ranked below technological and economical factors of design.

It is often the case that architects who are engaged in designing social housing with high-tech methods easily lose sight of the social aspect of residential architecture. Architects press for technological aesthetics, while failing to address social exclusion and the living requirements of a low-income population. An example of this technological and aesthetic inclination of social housing is Jean Nouvel's Nemasus I \& II in Rome. ${ }^{7}$ Located in a neighborhood of the 1960 s, this project harnesses prefabrication, recycles industrial elements such as bi-fold balcony doors, and meets intentionally minimal spatial requirements for dwelling units. The end result from this approach is high-quality housing for underprivileged members on the periphery of Rome.

However, in contrast to the initial intention of the architect - to create housing that is affordable, yet of high quality - what has emerged is an exclusive residential condominium. The aesthetic appearance of Nouvel's aeronautical form and rusted industrial components attracted the attention of well-todo members of society, leaving out the low income population for whom the project was initially conceived. In a sense, Nouvel's residential design approach resembles Bartleby's passivity, carried over into the social role of the architect in society. Nouvel's approach fails to pay proper attention to the social needs and capacity of the low-income population. It fails to meet the agenda of providing high-quality housing for people in need, a goal that is at the core of any program for social housing. With ecological tactics such as lowenergy construction methods (prefabrication and recycling of existing industrial doors), Nouvel surely contributes to the field of technological and aesthetic production of dwelling units. In this project, however, simply achieving the correct implementation of constructing methods, of technological components and an aero-dynamic form leads to the pitfall of elitism. His design takes the theme of social housing as a platform to examine the techno-aesthetic potential of sustainable measures. This will eventually result in an economic enterprise affordable only by middle- and upper-class members of the society. This failure to address the social, while the nature of the project is essentially social, is identified with Bartleby's I prefer not to attitude. 


\section{ECOLOGICAL MODERNIZATION AND ITS LIMITS}

One theory that gives legitimacy to the technological approach is what is commonly called ecological modernisation (it is also called ecological modernism.) This position is predicated upon a historical perspective that sees the resolution of the contemporary environmental problems as formulating a new industrial paradigm beyond the current logic of manufacturing. ${ }^{8}$ According to the social scientist Andrew Blower, ecological modernisation takes "the environmental challenges not as a crisis but as an opportunity" to restructure the industry on the global scale. In other words, ecological modernism resolves problems through "further innovation and the transition to an industrial society in which ecological protection and economic development are complementary rather than in conflict." 10 This position initiates a relatively optimistic view of the future: that transforming corporations and institutions will not only amend ecological problems but also will guarantee prosperity of the human population.

This optimism, along with its supposedly altruistic motivation, however, is found untenable when one takes into account other faces of ecological modernisation. First, the technological logic presented as an ecological solution "indicates the possibility of overcoming the environmental crisis without leaving the path of modernisation." 11 This leads to the preconditioned positivism reinforced with economic benefits, failing to problematise the ecological consequences of the industrial process. As Guy and Farmer note, this is because of the passive acceptance of "techno-economic change [with] an interactive approach in which science, technology, and management take account of the environmental impact of development." 12 Second, ecological modernisation gives rise to a social incoherence. As David Harvey argues, ecological modernisation results in a "greater dominance of global resources by transnational industry, national governments, and big scale in the name of sustainability." 13 An example of this practice is the adaptation of ecological regulations by corporations such as IBM. Impositions of "strong environmental regulations demanding high-tech solutions" are welcomed by the corporations. This is because the impositions "promised not only a competitive advantage to their own industries but also a strong export market for the more environmentally friendly technology they had developed." ${ }^{14}$ Such positioning of ecological modernisation sets an obvious win-win situation for major global corporations. It is also ironic that, according to David Pellow and his co-authors, companies involved in the resolution of ecological issues with the cause of saving the globe from environmental debacle provide very poor employment conditions ${ }^{15}$, a fact that is indicative of how the social aspect of ecology is neglected and considered only as an tangential matter at best. 
The impact of the position of ecological modernisation resonates in the realm of sustainable architectural practice. Sustainability is advertised as comprising innovative technological gadgets in the built environment (solar shading, translucent insulation, intelligent facade, photovoltaics, etc.), turning sustainable architecture into yet another mode of industrialisation. This allows sustainable architecture to bridge the double demands of high aesthetics and energy conservation within a framework of economic proficiency.

William McDonough's architecture provides an example of this practice. He uses design as the medium for bringing together ecological and economical benefits. McDonough stresses this strong economic-ecologic interdependence, which can be utilised as "models and mentors for human design". ${ }^{16}$ In particular, McDonough, along with Michael Braungart, develops the idea of "eco-effective design [which] demands a coherent set of principles based on nature's laws and the opportunity for constant diversity of expression." ${ }^{17}$ The eco-effective design can create a basis for more naturally-driven construction in which all materials come from the earth and "can be freely given back without causing harm to any living system." ${ }^{18}$ His design logic further differentiates two types of materials: industrial and natural. In this logic, "materials that might eventually decompose into the soil are considered parts of an ecological metabolism. Otherwise they were regarded as part of an industrial metabolism and might be leased from the manufacturer and eventually returned as a feedstock to be remanufactured into new product." ${ }^{19}$ By appropriating the phenomenon of natural decomposition for the logic of industrial production, McDonough theorises a new never-ending mode of industrialisation and celebrates a new set of ecological consumption habits.

The architectural practice of William McDonough+Partners seems to support Spaargaren and Mol's suggestion that "the only possible way out of ecological crisis is by going further into industrialisation." ${ }^{20}$ This is evident from the Flow House project, designed for a New Orleans community victimised during Hurricane Katrina. According to McDonough+Partners, the "Flow House reengages people with their natural surroundings, embedding the house within its context, site, and community through diverse exterior rooms that become extensions of interior living spaces." ${ }^{21}$ Although the building is designed with this communal intention, the process of design focuses more on performance of different materials and fails to recognise the social specificities of New Orleans' setting. McDonough+Partners fail to follow their own goals, which are "not simply [to] recognise and address economy, ecology, and social equity considerations, but to optimize and maximize values in all areas." ${ }^{22}$ Despite the 
strong social nature of the project, their design does not enter into a dialogue with future tenants concerning their situations and needs at the level of the individuals, families and neighborhood. The idea of "exterior rooms that become the extensions of interior living spaces" was an abstract idea of the architects as professional planners, not having emerged from their engagement with the local future residents. Thus, the project avoids addressing the importance of the community members as active participants in the process of designing dwelling units, while the professional architects govern the process with technological and spatial solutions. McDonough's design in the end operates upon a complete separation between the ecological aspects of design and the social setting of existing neighborhoods. Ecological modernisation, of which McDonough's theory and practice is a good example, depends on technological implementations for sustainability, while abstract and diagrammatic apprehension of social needs prevails. Here, the I prefer not to position in reference to the social aspects of architectural practice is once more repeated.

\section{INCREMENTAL HOUSING PROGRAM AS A FORM OF SOCIAL SUSTAINABILITY}

A position in contrast to ecological modernisation is participatory social sustainability. According to Nicola Dempsey, Glen Bramley, Sinéad Power and Caroline Brown, social sustainability and its correlate architectural practice draw freely from "concepts such as the sustainable communities, which is underpinned by, among other factors, social equity and justice." ${ }^{23}$ It seeks to establish a setting for long-term human activities for the proper operation of a community. The process includes concerns such as the shortage of energy and materials, shortage that operates not as an obstacle but as an agent for refreshed and augmented social bonds. Due to its nature of rooting architectural practice in the communal, social sustainability is a process without any teleological and fixed goal in terms of a techno-aesthetic agenda. Social sustainability is "neither an absolute nor a constant. Social sustainability has to be considered as a dynamic concept, which will change over time (from year to year / decade to decade) in a place. ${ }^{24}$

Architects pledge to address the daily needs of ordinary people and formulate a platform for their future purposes. The approach to housing in social sustainability not only examines formal, spatial and material aspects of design, but above all, takes into account the social setting of a particular location such as the composition of the members of a group, nature of the inter-personal human relationship, economic situations, and the availability of materials and 
construction methods. In terms of construction, social sustainability carries out locally acceptable, affordable and simple construction practice in consideration of the social and economic situations of inhabitants, families and groups. This approach does not support deductive design as the model, but - in the words of Perez de Arce and De Ferrari - it explores "an idea of excellence related to the attainment of the essential rather than the more limited scope of the minimal. ${ }^{25}$ This reductive mode of design praises the essential in contrast with the minimal that seeks to achieve the spatial and formal simplicity of a building.

An example of this practice is the Chilean housing project initiated by the forest company Arauco. ${ }^{26}$ The company commissioned architects from the Elemental group to develop a plan that would provide residential units to their employees and constructors. The result of this collaboration is the residential project of Villa Verde in the Maule region of Chile. Similar to their previous housing projects, for Villa Verde the Elemental architects reactivated the selfhelp housing program with an innovative typology for a higher standard of socially sustainable housing. Self-help housing programs in Latin American countries, as noted by Peter Ward, "were created between the mid-1950s and the middle of 1970s. ${ }^{27}$ They have continued to develop ever since, addressing the contemporary residential setting "that cannot be resolved using unilateral or standard approaches. ${ }^{.28}$ These programs refresh the significance of promoting social housing with a subsidised principle. The principle treats the construction process as an open system in order to establish a platform for self-built practices of community members. According to John Turner, "for local decision-maker or user, the open service system has a high degree of, or the capability for, providing many different ways of achieving the same end - in the present case, the construction of a house. ${ }^{29}$ For Turner, self-help construction "envisions housing as a process and not as a finished commodity. It permits donors to build what they consider essential according to their own financial capacity and priorities. Later, after initial occupancy, beneficiaries may modify and improve their homes according to their economic and social capabilities. ${ }^{30}$ The flexibility and adaptability of the housing program enables the involved families to join the project with low economic burden, while ecological impact on the natural setting remains minimal. The self-built housing approach becomes the prime means for a low income population to enter the land and housing market. ${ }^{31}$ For Burgess, the self-help housing program encourages citizens to build lowcost and high use-value dwelling units "so that the do-it-yourself component is complemented by dweller control, with government-guaranteed access to resources at the local level." ${ }^{32}$ 
According to Weissmann, this logic of design "can make a significant contribution toward improving housing and community services for the lower income families particularly if they are executed as part of a national housing policy and if they are supported by appropriate planning." ${ }^{.33}$ Indeed, the planning and design process of Villa Verde was assisted by the Supportive Housing Fund (el Fondo Solidario de Vivienda: FSV) offered by the Ministry of Housing and Urban Development (MINVU) of the government of the Republic of Chile. ${ }^{34}$ It is this funding program that has enabled low income families to purchase and construct a residential unit without mortgages in urban, semi-urban, and rural areas of Chile. The major strengths of FSV support are: 1) more flexibility and wider choices; 2) more social integration; 3 ) focus on members of the community who are in urgent need for housing; 4) effort award (additional options for saving); and 5) higher-quality residence units and better quality of life. ${ }^{35}$ With this development strategy, the Chilean government intends to lead the poor and the working class into a path of incremental prosperity. There was additional subsidiary aid from MINVU, called the Special Workers Program (SWP). The SWP "provides direct subsidies to organised groups with either large savings capacity than that of the basic housing beneficiaries or with assistance from other sources (employers, NGOs)." ${ }^{" 36}$ These governmental supports operated as a springboard for Elemental and Arauco in terms of launching a high-quality incremental housing program.

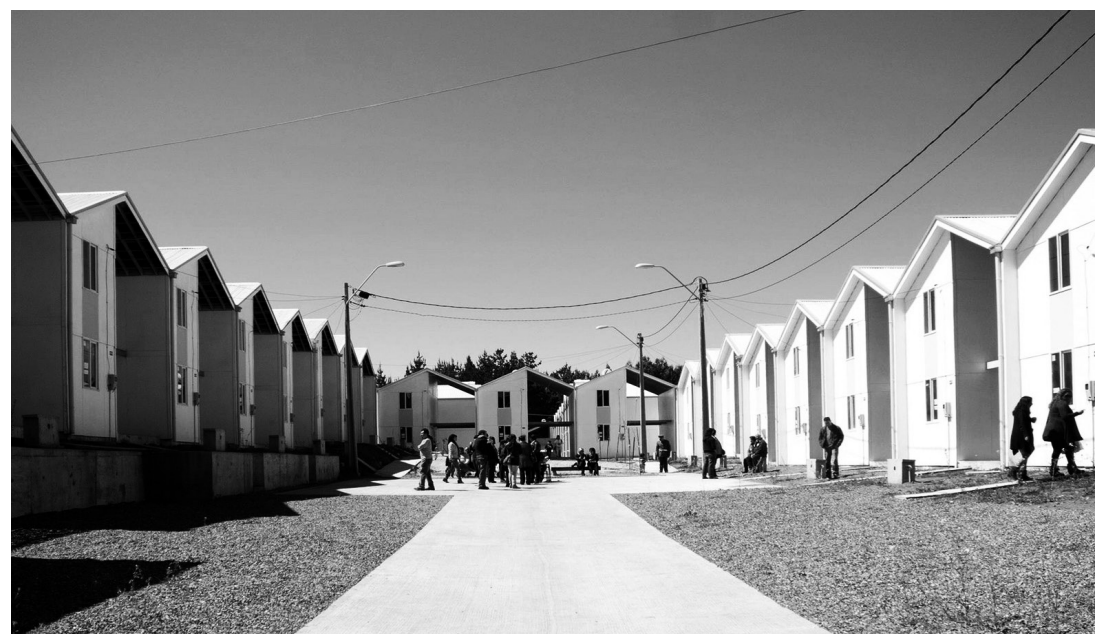

Fig. 1. Street view of Villa Verde neighborhood. Source: Villa Verde, Constitución (Chile), 2013. Elemental/ Photograph: Cristián Martinez | Elemental. 
Elemental's plan consists of multiple phases that ultimately will include a total of 9,000 housing units, and is expected to influence the development of 30 different towns and villages of between 10,000 and 20,000 people. ${ }^{37}$ Collaborating with community centers, the first phase included 484 residential units based on a row house typology laid along the gentle slope of the natural terrain. (Figure 1) Each unit is predicated upon a structural frame, one half of which is designed as a living place and the other half of which is intentionally left unfinished so that the inhabiting family can expand the living zone in accordance with their needs. Regarding this approach that defines the house as a project to be completed both by the architect and the dwellers, Alejandro Aravena said, "[...] half of our project is not built by ourselves, I mean, they're going to be built by families [...] I guess [that the] architect has a big say because it [sic] can synthesise complexity without reducing it, organise information so that we can move towards a proposal and not just a diagnosis." ${ }^{38}$ The significance of Aravena's approach is exactly the opposite of what John Chris Jones defines as a „dead metaphor“. For Chris Jones, "to think of design as problem-solving is to use a rather dead metaphor for a lively process and to forget that design is not so much a matter of adjusting to the status quo as of realizing new possibilities and discovering our reaction to them." ${ }^{39}$ Villa Verde is thus an embodiment of a living metaphor that looks upon design as an open-ended process in which not only the architect but also the dwellers play a quintessential role. The work operates as a catalyst for social equity, exemplifying a type of design that lays the foundation for social sustainability.

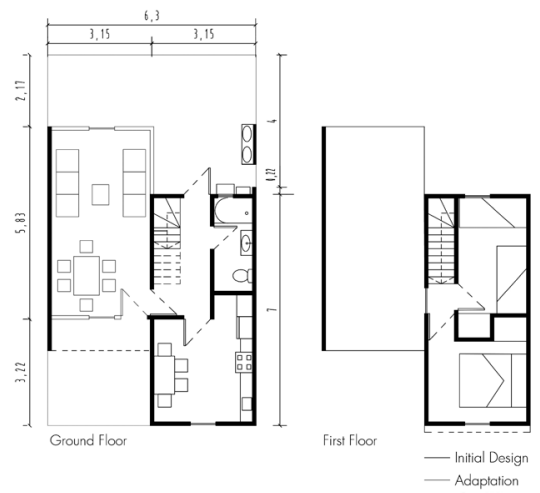

Fig. 2. Type A. First and second floor of a typical residential unit before and after the extension by residents. Drawn by the author based on Alejandro Aravena, Andrés Iacobelli, "Elemental: Incremental Housing and Participatory Design Manual," 2013.

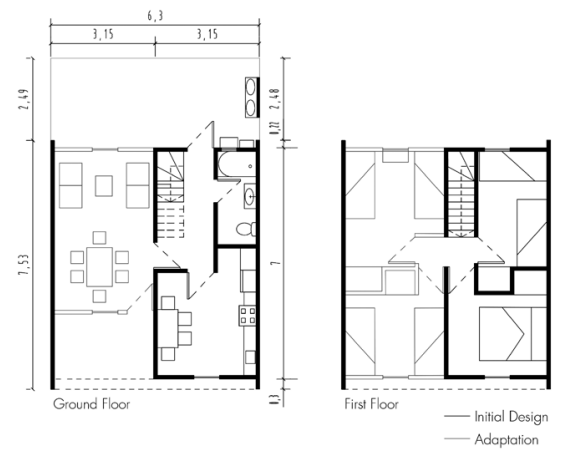

Fig. 2. Type B. First and second floors of a typical residential unit before and then after the extension by residents. Drawn by the author based on Alejandro Aravena, Andrés Iacobelli," Elemental: Incremental Housing and Participatory Design Manual," 2013. 


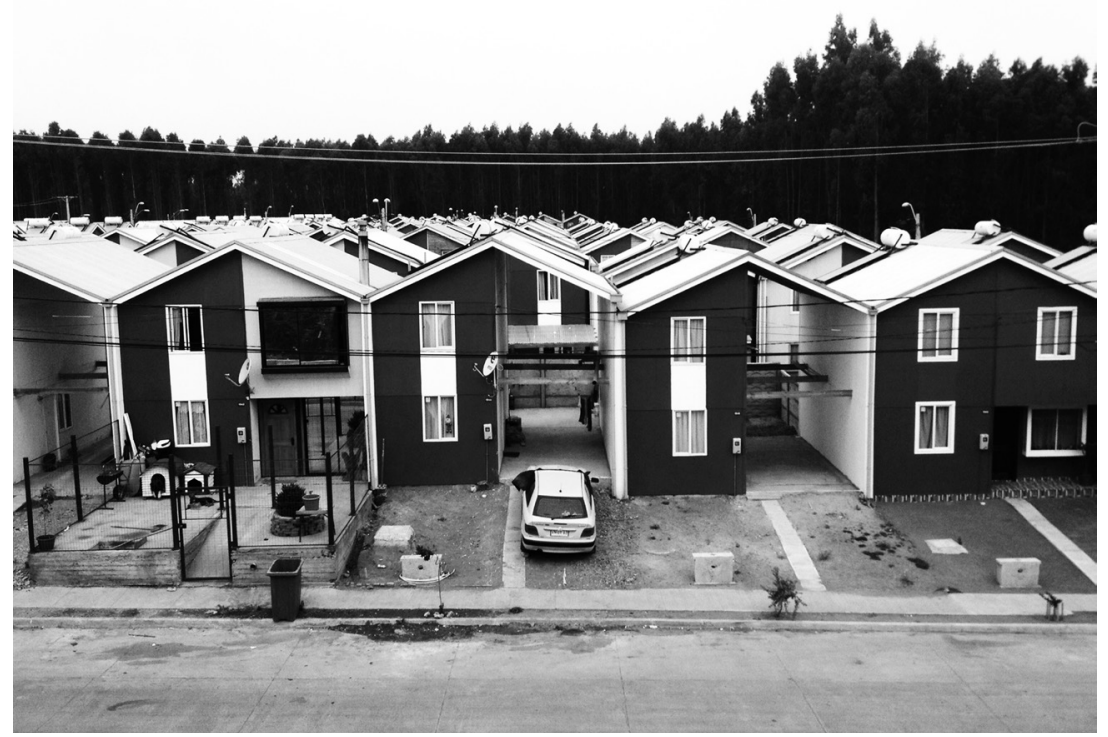

Fig. 4. Villa Verde, Constitución (Chile), February 2015. Source: by author.

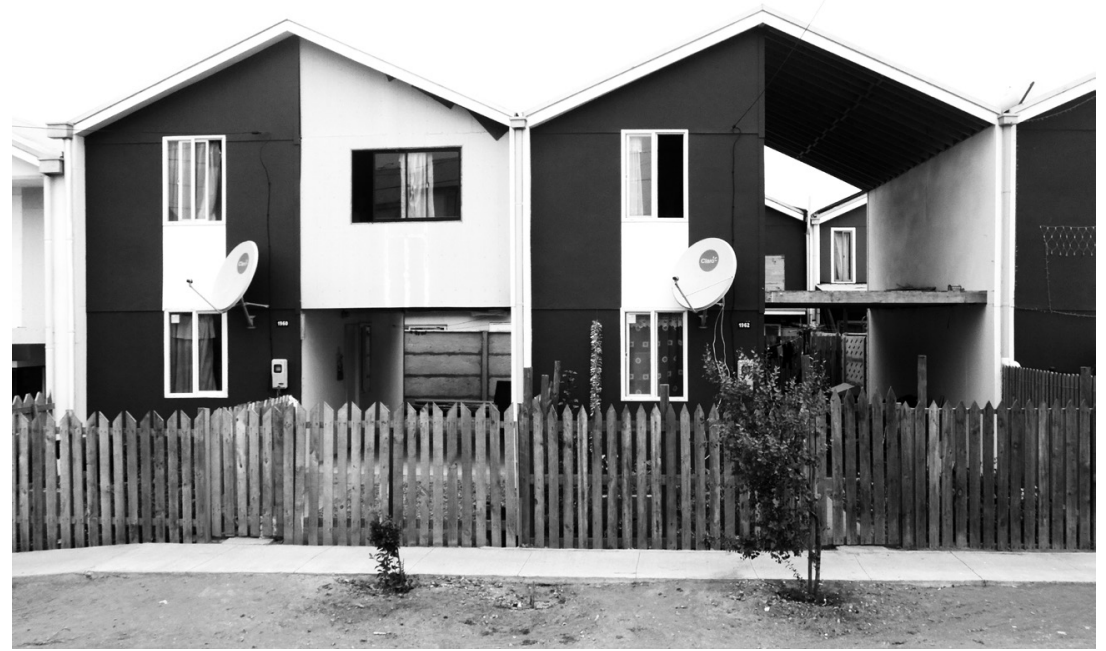

Fig. 5. Initially designed house and houses with a full expansion. Villa Verde, Constitución (Chile), February 2015. Source: by author. 
The project proceeded with two types of units; the first is initially designed as a 56.44 square meter unit which can be extended into the total of 64.90 squre meters, (Figure 2), and the second is a 56.88 square meter unit that can expand into 85.10 square meters (Figure 3). The initial phase of the house occupies a relatively small part of the land, with a standard unit of 3.15 meters in width and 7 meters in depth. The initial ground plan with the footprint of 22.05 square meters contains a hallway with a stairway, a bathroom, a kitchen, and a dining room. ${ }^{40}$ It is surrounded on two sides by a veranda to be handed over to occupants for self-building in response to their evolving needs of life. In this fashion, the project accomplishes its dualistic strategy to offer basic elements of the housing yet with room for tenants' free appropriation to suit their lifestyle. This strategy of a user-led extension is at the core of the socio-sustainable design, as the process acknowledges scarcity of resources and, in turn, encourages such sustainable measures as recycling of materials and the adoption of locally-available construction skills. The initial units are constructed with a machine-graded structural timber frame supported on a concrete foundation, interior cladding with $10 \mathrm{~mm}$ gypsum, an external cover of $6 \mathrm{~mm}$ fiber cement board for walls, and galvanised corrugated steel plates for neighbor by the in-between temporary veranda, or the second half of the house reserved for future expansion. The pinched roof tops form a continuous cover over both the initial area and the area to be expanded (Figures $4 \& 5$ ). The extension with materials and skills that are at hand is usually targeted at accommodating additional communal spaces, such as a living room on the ground floor and additional bedrooms on the first floor.

According to Turner, this strategy of building in phases is more appropriate than the conventional manner of building with no phases. It meets people's needs, allows room for personalisation, and strengthens family ties. Furthermore, it gives rise to a variegated community in which sameness and differences are mutually in operation: differences to reflect particular situations of each family in terms of configuring and constructing the extension and sameness for the shared overall framework. Thanks to this distinctive manner, the community as a whole is characterized by "the mix necessary for social change and development. ${ }^{" 41}$ At the same time, the extension process adjusts the given framework through the informal practice of trial-and-error, assigning vitality and diversity to the neighborhood. For reasons of economy and of the scarcity of materials, the most common choice of building materials for the walls in the extension is $8 \mathrm{~mm}$ gypsum board and versions of wood panels inserted with different types of doors and windows. This gives the extensions, designed and constructed by the residents, the color, texture, and morphology which ground the project in its setting. 
Elemental's social approach is less hazardous to the environment because of its on-going process of absorbing wasted materials. The materials used for constructing extensions of the houses are recycled from local sides or purchased as new materials in nearby storehouses. By narrowing down the transportation cost of materials and by supporting community bonds in the process of negotiating the price and the quality of materials, the project reaches a maximal quality of construction with less harmful impact on natural resources. This design methodology thus bridges the gap between ecological protection and the social requirements of the community. Constructing housing with participatory practices, while acknowledging scarcity of materials, not only scales down the ecological footprint, but also provides future tenants with "exactly what they want." ${ }^{42}$

\section{CONCLUSION: TOWARD PARTICIPATORY ARCHITECTURE}

The technological approach to sustainability such as ecological modernisation seeks "the possibility of overcoming the environmental crisis without leaving the path of modernisation." ${ }^{43}$ This position further believes that the current environmental problems can be resolved through another transformation of the industrial system on the global scale to replace the current one. This positivism of technological solutions is further augmented by an opportunity to revitalise the economy stalled by the demand to preserve natural resources. It sees no conflict between ecological protection and economic development, seeking to be another universal mode of progress. This technological approach survives on and perpetuates the current imbalance in international political and economic systems, necessarily contaminating ecology with business-oriented management tactics. Social intolerance persists here, exacting a "survival of the fittest" mode upon regions across the globe.

A major problem of the technological approach lies in its homogenising view, i.e. a failure to accept and acknowledge unequal conditions and situations of different localities and their distinctive social structures. What is required instead is an approach more sensitive to regional conditions and social needs of the local residents. In other words, the socially sustainable approach is critical of any identified "style of design which is unequivocally sustainable architecture", and is skeptical of a "fixed set of rules which will guarantee success if followed." ${ }^{44}$ Unlike the technological positivism that operates upon a fixed set of regulations, tools and devices, the social sustainbility is "an ongoing transformational process in which different actors" interests and struggles are located." 45 
At the level of architecture, the social sustainability establishes a creative alliance and working partnership between citizens, the profession of architecture and governmental policies. In this regard, participatory sustainability is a pragmatic and humanitarian response to the social problems of different communities, using methods such as on-site construction, local supply of materials, userfriendly (convivial) technologies, re-use of materials and user participation as labour force. What is most significant is the fact that this participatory practice enhances the communal bond between individuals. This is a bond that operates not only between family members but between members of the community in general. This type of practice represents a bottom-up approach that emphasises improvement of housing over time, flexibility and local management of the construction process. The result of the practice is not an aesthetic object for a high-end style of living but a setting that puts emphasis on functionality over appearance.

An outstanding example of the social participatory approach is Villa Verde by Elemental. Its participatory approach is guaranteed by the dualistic strategy that provides basic elements of housing yet leaves meaningful room for extension by the future tenants that goes hand in hand with their lifestyles. This user-led extension naturally acknowledges scarcity of resources in terms of materials, construction techniques and labor, and conversely encourages such sustainable measures as recycling of materials, adoption of locally-available construction skills, and social contacts characterised by negotiations, compromises and collaborations. Of course, Villa Verde has its limitations. One example would be the presence of the supportive wall between the two halves. Its location as a structural wall separates the living zone on the ground level into two divided parts, functioning as a hindrance if one seeks to formulate a more flexibile and free flow of living between the two parts. Probably, this inflexibility is due not so much to the design itself as to the inherently inflexible industrial prefabrication techniques. Another disadvantage of Villa Verde consists of the provision of standardised dimensions for rooms as defined by the long and narrow bays. With respect to this, Schneider and Till wrote, "Determining a standard width for any room determines a fixed configuration of furniture, which in turn fixes patterns of use." ${ }^{\prime 6}$ Despite these limits, Villa Verde's programme based upon user-participation, continual adjustments to the availability of local resources, and commitment to social equity defines it as a paradigmatic example for sociosustainable residential architecture. This work joins the ecological aspect of design inseparably with the social aspect, establishing unequivocally the human bond as the ultimate foundation for sustainability. 

Comparison (London: Academy Press. 2001). Technology," Journal of Architectural Education 54 (2001): 140-148.

Ibid.

Philippe Jaworski. Melville: Le désert et l'empire (Paris: Editions Rue d'Ulm. 1986).

Gilles Deleuze, "Bartleby; or, The Formula," in Essays Critical and Clinical (London: University of Minnesota Press, 1997).

Richard Rorty, Achieving Our Country: Leftist Thought in Twentieth-Century America (London: Harvard University Press, 1999).

Olivier Boissière, Jean Nouvel (Terrail: Trilingual Edition, 1997).

Peter Christoff, "Ecological Modernisation, Ecological Modernities," Environmental Politics 5 (1996): 476-500.; Marten Hajer, "Ecological Modernisationas Culturalpolitics," in Environment and Modernity: Towards a New Ecology, eds. Scott Lash, Bronislaw Szerszynski, and Brian, Wynne (London: SAGE. 1996).; Arthur Mol, Refinement of Production: Ecological Modernization Theory and the Chemical Industry (Utrecht: van Arkel. 1995).

Andrew Blowers, "Environmental Policy: Ecological Modernisation or the Risk Society?," Urban Studies 34 (1997): 845-71.

Arthur Mol, "Ecological Modernisation and Institutional Reflexivity: Environmental Reform In the Late Modern Age," Environmental Politics 5 (1996): 302-23.

Gert Spaargaren and Arthur Mol, "Sociology, Environment, and Modernity: Ecological Modernization as a Theory of Social Change," Society \& Natural Resources 5 (1992): 323-44.

Simon Guy and Graham Farmer, "Reinterpreting Sustainable Architecture: The Place of Technology," Journal of Architectural Education 54 (2001): 140-148. .

David Gibbs, "Prospects for an Environmental Economic Geography: Linking Ecological Modernization and Regulationist Approaches," Economic Geography 82 (2006): 193-215.

David Harvey, Justice, Nature and the Geography of Difference (Oxford: Wiley-Blackwell, 1997).

David Pellow, Allan Schnaiberg and Adam, Weinberg, "Putting the Ecological Modernization Thesis to the Test: The Promises and Performance of Urban Recycling," in Ecological Modernizaton Around the World: Perspectives and Critical Debates, eds. Arthur Mol and David Sonnenfeld (London: Frank Cass Publisher. 2000).

William McDonough, "Design, Ecology, Ethics and the Making of Things," The Cathedral of St. John the Divine 3-9 (1993): 1993.

Michael Braungart and William McDonough, Cradle to Cradle: Remaking the Way We Make Things (London: Macmillan. 2010).

William McDonough, "Design, Ecology, Ethics and the Making of Things."

David Orr, The Nature of Design: Ecology, Culture, and Human Intention (New York: Oxford University Press. 2004).

Gert Spaargaren and Arthur Mol, "Sociology, Environment, and Modernity: Ecological Modernization as a Theory of Social Change," Society \& Natural Resources 5 (1992): 323-44.

William McDonough, "William McDonough+Partners, Charlottesville, VA.," in Architecture in Time of Needs: Making It Right Rebuilding New Orleans ' Lower Ninth Ward, ed. Kristin Feireiss (Munich: Prestel Publishing. 2009).

William McDonough. "Cradle to Cradle: Making it Right," in Architecture in Time of Needs: Making It Right Rebuilding New Orleans ' Lower Ninth Ward, ed. Kristin Feireiss (Munich: Prestel Publishing. 2009). 
Nicola Dempsey, Glen Bramley, Sinéad Power, and Caroline, Brown, "The Social Dimension of Sustainable Development: Defining Urban Social Sustainability," Sustainable Development Sust. Dev. 19 (2011): 289-300. 2011.

Ibid.

Rodrigo Perez de Arce and Felipe de Ferrari, "The Raw and the Cooked: Present and Future in Quinta Mnoroy, Iquique, Chile," in Housing Models. Experimentation and Everyday Life, eds. Oliver Elser, Michael Rieper and Christina Nägele (Vienna: Künstlerhaus Wien, Folio Verlag Wien- Bozen. 2008).

Alejandro Aravena and Gonzalo Arteaga, "Proyecto Villa Verde Constitución, Chile Elemental," in Elemental Obras y Proyectos (2013), 48-51. [In Spanish] The key persons in Arauco company which initiated Villa Verde are Matías Domeyko and Chareles Kimber.

Peter Ward, "The Rehabilitation of Consolidated Irregular Settlements in Latin American Cities: Towards a Third Generation of Public Policy Housing Analysis and Development," ESF Workshop: Coping with Informality and Illegality in Human Settlements in Developing Countries, 23-26. 2001.

Sergio de Azevedo, "Housing Policies in Latin America: The Myths of Self-Help Construction," PS: Political Science \& Politics 20 (1987): 895-901.

John Turner, "Housing as a Verb," in Freedom to Build, eds. John Turner and Robert Fichter (London: Collier Macmillan Ltd. 1973).

John Turner, "Housing in three dimensions: Terms of reference for the housing question redefined," World Development 6 (1978): 1135-45.

Alan Gilbert and Peter Ward, Housing, the State and the Poor: Policy and Practice in Three Latin American Cities (Cambridge: Cambridge University Press. 1985).

Rob Burgess, "Petty Commodity Housing or Dweller Control? A Critique of John Turner's views on Housing Policy," World Development 6 (1978):1105-33.

Ernest Weissmann, "Mutual Aid in Low-Cost Housing," The Annals of the American Academy of Political and Social Science (1960): 107-114.

The Ministry of Housing and Urban Development. Government of the Republic of Chile. http:// www.minvu.cl/opensite 20120504121302.aspx. 2015. [In Spanish]

Ibid.

Eduardo Rojas, "The Long Road to Housing Sector Reform: Lessons from the Chilean Housing Experience," Housing Studies 16 (2001): 461-83.

Alejandro Aravena and Andrés Iacobelli. Elemental: Incremental Housing and Participatory Design Manual (Berlin: Hatje Cantz. 2013).

Ken Tadashi Oshima, Alejandro Aravena: The Forces In Architecture (Tokyo: Toto Publisher. 2011).

John Chris Jones, Design Methods (New York: John Wiley \& Sons. 1992).

Fundacion Gestion Vivenda, Constitución - Villa Verde: Alto Estándar en Vivienda Social, http:// www.gestionvivienda.cl/web/reconstruccion/villa-verde/. 2013. [In Spanish]

John Turner, "Barriers and Channels for Housing Development in Modernizing Countries," Journal of the American Institute of Planners 33 (1967): 167-81.

Design Council. Competitive Advantage through Design (London: Design Council. 2002).

Gert Spaargaren and Arthur Mol, "Sociology, Environment, and Modernity: Ecological Modernization as a Theory of Social Change," Society \& Natural Resources 5 (1992): 323-44.

Antony Radford, Helen Bennetts and Terry Williamson, Understanding sustainable architecture (London: Spon Press. 2003).

Ann Long and Norman Long, Battlefields of Knowledge: the Interlocking of Theory and Practice in Social Research and Development (London: Routledge. 1992).

Tatjana Schneider and Jeremy Till, "Flexible housing: opportunities and limits," Architectural Research Quarterly 9 (2005): 157-166. 
Aravena, Alejandro, and Andrés Iacobelli. Elemental: Incremental Housing and Participatory Design Manual. Berlin: Hatje Cantz. 2013.

Aravena, Alejandro, and Gonzalo Arteaga. "Proyecto Villa Verde Constitución, Chile Elemental." Elemental Obras y Proyectos (2013): 48-51.

Azevedo, Sergio, de. "Housing Policies in Latin America: The Myths of Self-Help Construction." PS: Political Science \& Politics 20 (1987): 895-901.

Blowers, Andrew. "Environmental Policy: Ecological Modernisation or the Risk Society?.” Urban Studies 34 (1997): 845-71.

Braungart, Michael, and William McDonough. Cradle to Cradle: Remaking the Way We Make Things. London: Macmillan. 2010.

Deleuze, Gilles. Bartleby; or, The Formula In Essays Critical and Clinical. London: University of Minnesota Press. 1997.

Dempsey, Nicola, Glen Bramley, Sinéad Power and Caroline, Brown. "The Social Dimension of Sustainable Development: Defining Urban Social Sustainability.” Sustainable Development Sust. Dev. 19 (2011): 289-300.

Design Council. Competitive Advantage through Design. London: Design Council. 2002.

Edwards, Brian. "Design Challenge of Sustainability." In Green Architecture: An International Comparison. London: Academy Press, 2001.

Feireiss. Kristin. Architecture in Time of Needs: Making It Right Rebuilding New Orleans' Lower Ninth Ward. Munich: Prestel Publishing. 2009.

Fundacion Gestion Vivenda, Constitución - Villa Verde: Alto Estándar en Vivienda Social. Available at: http://www.gestionvivienda.cl/web/reconstruccion/villa-verde/. 2013. [In Spanish]

Guy, Simon, and Graham Farmer. "Reinterpreting Sustainable Architecture: The Place of Technology.” Journal of Architectural Education 54 (2001): 140-148.

Gilbert, Alan, and Peter Ward. Housing, the State and the Poor: Policy and Practice in Three Latin American Cities. Cambridge: Cambridge University Press.1985.

Gibbs, David. "Prospects for an Environmental Economic Geography: Linking Ecological Modernization and Regulationist Approaches.” Economic Geography 82 (2006): 193-215.

Harvey, David. Justice, Nature and the Geography of Difference. Oxford: Wiley-Blackwell. 1997.

Jones, John Chris. Design Methods. New York: John Wiley \& Sons. 1992.

Lash, Scott, Brian Wynne and Bronislaw Szerszynski. Environment and Modernity: Towards a New Ecology. London: SAGE. 1996.

Long, Ann, and Norman Long. Battlefields of Knowledge: the Interlocking of Theory and Practice in Social Research and Development. London: Routledge. 1992.

McDonough, William. "Design, Ecology, Ethics and the Making of Things." The Cathedral of St. John the Divine 3-9 (1993): 1993.

Mol, Arthur, and David Sonnenfeld. Ecological Modernizaton Around the World: Perspectives and Critical Debates. London: Frank Cass Publisher. 2000.

Mol, Arthur. "Ecological Modernisation and Institutional Reflexivity: Environmental Reform In the Late Modern Age.” Environmental Politics 5 (1996): 302-23.

Mol, Arthur. Refinement of Production: Ecological Modernization Theory and the Chemical Industry. Utrecht: van Arkel. 1995.

Oliver, Elser, Michael, Rieper, and Christina, Nägele. Housing Models. Experimentation and Everyday Life. Vienna: Künstlerhaus Wien, Folio Verlag Wien- Bozen. 2008.

Olivier, Boissière. Jean Nouvel. Terrail: Trilingual Edition. 1997. 
Orr, David. The Nature of Design: Ecology, Culture, and Human Intention. New York: Oxford University Press. 2004.

Oshima, Ken Tadashi. Alejandro Aravena: The Forces In Architecture. Tokyo: Toto Publisher. 2011.

Pellow, Allan, Schnaiberg, and Adam, Weinberg. "Putting the Ecological Modernization Thesis to the Test: The Promises and Performance of Urban Recycling" London: Frank Cass Publisher. 2000.

Peter, Christoff. "Ecological Modernisation, Ecological Modernities." Environmental Politics 5 (1996): 476-500.

Peter, Ward. The Rehabilitation of Consolidated Irregular Settlements in Latin American Cities: Towards a Third Generation of Public Policy Housing Analysis and Development. ESF.

Philippe, Jaworski. Melville: Le désert et l'empire. Paris: Editions Rue d'Ulm. 1986.

Radford, Antony, Helen Bennetts and Terry Williamson. Understanding sustainable architecture. London: Spon Press. 2003.

Richard, Rorty. Achieving Our Country: Leftist Thought in Twentieth-Century America. London: Harvard University Press. 1999.

Rod, Burgess. "Petty Commodity Housing or Dweller Control? A Critique of John Turner's views on Housing Policy.” World Development 6 (1978): 1105-1133.

Rojas, Eduardo. "The Long Road to Housing Sector Reform: Lessons from the Chilean Housing Experience." Housing Studies 16 (2001): 461-83.

Schneider, Tatjana, and Jeremy Till. "Flexible housing: opportunities and limits." Architectural Research Quarterly 9 (2005): 157-166.

Spaargaren, Gert, and Arthur Mol. "Sociology, Environment, and Modernity: Ecological Modernization as a Theory of Social Change." Society \& Natural Resources 5 (1992): 323-44.

The Ministry of Housing and Urban Development, Government of the Republic of Chile, http:// www.minvu.cl/opensite_20120504121302.aspx. 2015. [In Spanish]

Turner, John. "Barriers and Channels for Housing Development in Modernizing Countries." Journal of the American Institute of Planners 33 (1967): 167-81.

Turner, John. "Housing in three dimensions: Terms of reference for the housing question redefined." World Development 6 (1987): 1135-1145.

Turner, John and Robert Fichter. Freedom to Build. London: Collier Macmillan Ltd. 1973.

Weissmann, Ernest. "Mutual Aid in Low-Cost Housing." The Annals of the American Academy of Political and Social Science (1960): 107-114.

Workshop: Coping with Informality and Illegality in Human Settlements in Developing Countries, 23-26. 2001. 


\section{FAKTOR PARTICIPACIJE U ODRŽIVOSTI NAKON TEHNOESTETIZMA I EKOLOŠKE MODERNIZACIJE \\ Goran Ivo Marinović}

Disperzivno tumačenje ekoloških tema u arhitekturi stvara osnov za konfuziju i kontradiktornosti svojstvene izazovima održivog. Odnos između održivosti i njenog prezentovanja u arhitekturi je problematičan. U savremenoj arhitektonskoj praksi termin održivosti je često nešto više od modernog izraza ili pogodne reči. Analiziranjem bezbrojnih projekata, članaka i knjiga na temu održivog projektovanja, očigledno je da je održiva arhitektura inkorporirala nepotrebno ograničenu i neadekvatnu konceptualizaciju ekologije društva. U cilju prevazilaženja ove deduktivne logike održive arhitekture, ovaj rad ima dva cilja. Prvo, istražuje različite ideje ekološke održivosti. Ovaj rad tvrdi da se u osnovi moraju revidirati fokus i obim rasprave o održivoj arhitekturi. Kao drugo, kroz rad Čileanskih arhitekata Elemental-a, ovaj rad razjašnjava pitanja procesa projektovanja u izgradnji stambenih jedinica poštujući praksu participacije članova zajednice i istražuje proces projektovanja stanovanja u kontekstu društveno-ekoloških aspekata. Kroz konkretisanje argumenta, ovaj rad istražuje najdominantnije interpretacije ekoloških i društvenih karakteristika $\mathrm{u}$ arhitektonskom procesu projektovanja stanovanja.

KLJUČNE REČI: FAKTOR PARTICIPACIJE U ODRŽIVOSTI, STAMBENA ARHITEKTURA, ELEMENTAL

\section{INTEGRISANI TRŽNI CENTAR KAO KOMPONENTA KOMPAKTNOG GRADA Marija Cvetković, Ivan Simić}

U ovom radu je prikazan koncept kompaktnog grada koji, za razliku od drugih koncepta održive urbane forme, gotovo u potpunosti uključuje sve relevantne teme održivog urbanog razvoja, kao što je povećanje gustine razvoja, kombinovanje funkcija, širenje grada, kao i postizanje socijalne i ekonomske raznolikosti i vitalnosti. Integrisane tržne centre ćemo posmatrati kao komponente kompaktnog grada i uspostavićemo njihov odnos sa konceptom kompaktnog grada i njegovim karakteristikama. Koncept tržnog centra u istorijskom gradskom jezgru nije izvorno održiv koncept. Umesto toga, urbana reciklaža starih industrijskih objekata koji se nalaze u blizini centra grada u funkciji maloprodaje se smatra održivijim konceptom i može se smatrati komponentom kompaktnog grada. Cilj ovog istraživanja je da se ispita značaj integrisanog pešačkog okruženja za urbani prostor u okviru koncepta kompaktnog grada. U cilju utvrđivanja stepena kompatibilnosti između principa održivog urbanog oblika i principa dizajna integrisanog tržnog centra, analiziraćemo nekoliko studija slučaja trgovačkih centara u Češkoj i Poljskoj.

KLJUČNE REČI: KOMPAKTNI GRAD, INTEGRISANI TRŽNI CENTAR, ODRŽIVA URBANA FORMA, URBANA RECIKLAŽA 